\title{
PENANGANAN LIMBAH INDUSTRI DENGAN CARA IMMOBILISASI MICROBIAL CELI
}

\author{
Oleh : Prayitno
}

\section{ABSTRACT}

in cell to a

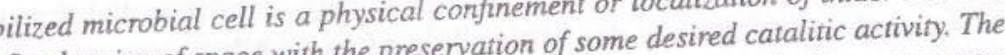
ertain defined region of space with the presenvation of some desined cone is for waste water rell process has been increasingly used, one of those is for waste water Microbial entrapping process one of the method for the microbial cell reatment industry. Microbial entrapping process ollagen, gelatin, alginate, carragena and mmobilization by using some carrier such as collagen, gelatin, alginate, carragena and ellulose tri acetat at the time being is conmonly used. Immobilization cell is effective immobior waste water treatment containing toxic substance such as pher

secondary sedimentation tanks is no longer u

\section{INTISARI} mmobilisasi mikrobia cell merupakan suatu cara untuk melokalisasi atau menaha secarai physis cell lengkap pada tempat tertentu dengan memelihara aktiftas katalitik cell sesuai lengan yang dïnginkar. Penggunaan immobilisasi cell saal ini ierus meningkabilisasi satunya adalah penggunaannya untuk pengolahan limbah cair industri. Proses imert collagen, cell dengan cara menjerat mikrobia dengan berbagai bahan pemban metoda yang banyak gelatin, agar alginat, carrogen, cellulose iri acetat saat ini menupakan me cukup ting gi untuk digunakan. Metoda immobilisasi cell dapat memberikan efektifitas yang cukap ting tidak lagi mengolah limbah cair yang mengandung bahan tokste seperti phem

diperlukan pengendap sekunder dalam proses pengolahan limbanny.

\section{PENDAHULUAN}

mebaga katisator untuk keperluan industri, analisa dan dunia kesehatan telah berkembang dengan pesatnya sejak dua dekade terakhir ini,

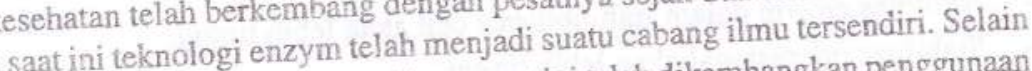
untukerluan-keperluan tersebut diatas, saat ini telah dikembangkan penggunaan enzym untuk keperluan penanganan limbah industri baik melalui pencegahan yaitu eknologi bersih maupun dalam penanggulangannya.

dengan penerapan teknologi bersih maupun dalam penanggulangannya. kususnya limbah Penggunaan enzym untuk penanganan limbah industia suatu media cair dapat dilakukan dengan mengimmobilisasi enzym dase padat yang digunakan Sedemikian rupa sehingga menyerupai katalsalah merupakan suatu zat yang dapat untuk reaksi-reaksi kimia sintetik. Enzy hidup, akan tetapi untuk keperluan dalam diproduksi oleh hampir semua mahluk hidup, an dihasil-kan oleh microbia bidang industri, yang lebih sesuai adalah enzym yang dit

Vol. XII No. 24 Th. 1996/1997 


\section{likarenakan beberapa alasan diantaranya :}

Biaya produksi rendah,

Kondisi untuk produksi tidak dibatasi lokasi maupun iklim,

Waktu yang diperlukan untuk produksi secara massal,

Dimungkinkan untuk diproduksi secara massal.

Enzym yang dihasilkan oleh mikrobia dapat diklasifikasikan menjadi dua rrup, yaitu :

Extracellulair Enzym ialah jika enzym yang dihasilkan diekskresikan dari cell ke media pertumbuhan dan Intracellulair Enzym bila enzym yang dihasilkan etap tinggal didalam cell selama pertumbuhannya.

Untuk menggunakan Intracellulair Enzym perlu dilakukan ekstraksi terlebih dahulu dari cellnya, dalam hal ini sering dijumpai hasil ekstraksi enzym tidak sesuai dengan yang dikehendaki dan tidak sesuai dengan immobilisasi enzym, selain itu biaya untuk ekstraksi enzym dirasa sangat mahal.

Dalam immobilisasi enzym diperlukan proses ekstraksi dan pemurnian untuk menghindari adanya problema tersebut dapat dilakukan dengan cara mengimmobilisasi seluruh cell microbia dan digunakan sebagai katalis padat.

Reaksi dengan cell microba yang diimmobilisasi dapat memberikan keuntungan bila :

Enzym yang dihasilkan adalah enzym extracellulair,

Microorganisme yang terkandung didalam imobilisasi cell tidak mempengaruhi enzym atau bila berpengaruh harus dengan mudah di inaktifkan atau dihilangkan, Substrate dan produksinya harus berupa bahan yang mempunyai berat molekul rendah.

Dengan kondisi seperti tersebut diatas, metoda cell mikroba yang di immobilisasi dapat memberikan keuntungan antara lain :

Proses untuk ekstraksi atau purifikasi enzym atau keduanya tidak diperlukan lagi,

Aktivitas enzym dalam immobilisasi cell akan lebih tinggi,

Stabilitas operasional akan lebih tinggi,

Biaya rendah,

Memungkinkan beberapa step reaksi enzym.

\section{METODE IMMOBILISASI CELL}

Telah banyak dipublikasikan metode immobilisasi cell, akan tetapi pada dasarnya metoda tersebut dapat diklasifikasikan dalam 3 kategori :

Majalah Barang Kulit, Karet dan Plastik

\section{Metode carrier - Binding}

Metode carrier - Binding adalah metode immobilisasi cell yang didasarkan pada pengikatan langsung dari cell ke dalam bahan pembawa (carrier) yang tidak larut dalam air.

Ikatan ini dapat secara aborsi phisik, ikatan ionik atau ikatan kovalent.

Sebagai carrier yang tidak larut dalam air dapat digunakan polysaccharida (cellulose, dextron dan derivat agar), protein (gelatin dan albumin), polymer sintetis (Ion exchange Resin dan PVC) dan material in organik (batubata, pasir, glassporous). Absorpsi cell kedalam bahan pembawa adalah sangat bergantung kepada karakteristik dari lingkungan, sebab phenomena absorpsi utamanya didasarkan pada interaksi elektrostatis (Van Der Walls forces) dan pada ikatan ionik dan hidrogen antara permukaan cell dengan bahan pebawa.

Metode ikatan kovalent merupakan metode yang sering digunakan dalam teknikteknik immobilisasi enzym, sebab akan didapat enzym yang stabil dalam pengoperasiannya. Akan tetapi untuk immobilisasi cell metoda ini tidak digunakan secara luas sebab toksisitas dari adanya coupling agent, yang mana akan menghilangkan aktivitas enzym dan kelangsungan hidup microbia.

\section{Metoda Cross Linking}

Cell dapat di immobilisasi secara cross linking dengan dua atau multifungsional reagent seperti glutaraldehyde, toluent diisocyanate dan lain-lain. Metode ini belum digunakan karena belum banyak studi tentang metode ini. Penelitian yang pernah dilakukan adalah dengan mengimmobilisasi cell E. colli, yang mempunyai aktivitas aspartase yang tinggi, secara cross linking antara dinding cell atau membrane cell dengan bifungsional reagent glutaraldehyde dan toluene diisocyanate. Dari percobaan didapat bahwa dengan menggunakan glutaraldehyde, cell masih memiliki aktivitas aspartase sekitar $34 \%$ akan tetapi penggunaan toluene diisocyanate dengan 1,6 diaminohexane cell menjadi inactive.

\section{Metode Entrapping}

Metode entrapping adalah metode immobiisasi dengan menjerat secara langsung cell ke dalam polymer sebagai bahan pembawa. Bahan polymer yang digunakan diantaranya adalah collagen, gelatin, agar alginate, carragen, cellulosa triacetat, polyacrilamyde dan poly urethane. Dari bahan-bahan tersebut diatas yang banyak digunakan adalah poly acrylamyde gel, alginate gel, K. Carragenan.

\section{TEKNIS PENYIAPAN IMMOBILISASI CELL}

Sehubungan dengan metode entrapping merupakan metode yang banyak

Vol. XII No. 24 Th. 1996/1997 
digunakan dalam immobilisasi cell proses, maka teknis penyiapan immobilisasi disini akan lebih dititik beratkan pada metode dengan menjerat langsung cell ke dalam bahan pembawanya (carrier). Bahan pembawa yang dapat digunakan antara lain :

\section{a. K. Carragen}

$\mathrm{K}$. Carragenan adalah bahan pembawa (carrier) yang sangat mudah didapat dan merupakan polysaccharide yang non tonic dihasilkan dari isolasi tumbuhan laut. Bahan ini tersusun dari $\beta$ D. Galactose Sulfit dan 3,6-anhydro- $\alpha$.D. Galactose. $\mathrm{K}$. Carragenan akan menjadi gel dengan pendinginan atau kontak dengan zat yang mengandung zat penggel seperti $\mathrm{K}+, \mathrm{NH} 4, \mathrm{Ca} 2+, \mathrm{Cu}+, \mathrm{Mg} 2+, \mathrm{Fe} 3+$, amonia.

Keuntungan dengan menggunakan K. Carragenan adalah bahwa immobilisasi dapat dibentuk dibawah kondisi temperatur normal tanpa menggunakan bahan kimia yang dapat menghancurkan aktifitas enzym yeng diperlukan. Aktifitas enzym dan microba cell immobilisasi akan mendapatkan hasil yang baik dengan menggunakan $\mathrm{K}+$ ion.

Keuntungan menggunakan $\mathrm{K}$. Carragenan adalah bahwa bentuk dari immobilisasi cell dapat dibuat sedemikian rupa sesuai dengan yang dikehendaki. Tambahan lagi bila immobilisasi cell dibuat dengan bahan peng-gel disuspensikan dalam larutan garam psikologis, K. Carragenan gel akan dengan cepat terlarut dan akan didapat suspensi cell bebas dalam larutan garam psikologis, hal ini akan memudahkan dalam pengamatan cell sesudah di immobilisasi. Kekurangan dalam penggunaan K. Carragenan adalah bahwa bila penggel tidak ada dalam campuran, cell akan dilepas dengan pengenceran gel, juga zat peng-gel dapat menghambat aktifitas-aktifitas enzym.

\section{Calsium Alginat}

Alginat yang merupakan hasil penyarian dari tumbuhan laut adalah copolymer linier dari D. Mannuronic dan L. Guluronic acid. Bahan dalam larutannya akan membentuk gel dengan multivalension seperti kalsium dan aluminium. Untuk immobilisasi cell, crosslinking alginat dengan $\mathrm{Ca} 2+$ adalah merupakan metode yang banyak digunakan, metode ini telah banyak digunakan untuk immobilisasi cell yang sangat sensitif seperti cell tumbuh-tumbuhan dan protoplasma.

Fleksibilitas dari metode ini dapat digambarkan sebagai berikut :

Alginat dengan berat molekul dan susunan kimia yang berbeda dapat digunakan.

Dapat digunakan dengan konsentrasi 0,5 - $10 \%$.

Konsentrasi $\mathrm{CaCl} 2$ untuk presipitasi dapat divariasi antara $0,05-2 \%$.

Temperatur digunakan antara $0-8^{\circ} \mathrm{C}$.

Majalah Barang Kulit, Karet dan Plastik
Cell loading dapat tinggi (sampai diatas 30 gram berat cell per $\mathrm{ml}$ katalisator).

c. Cellulose

Cellulose merupakan bahan organik dari derivat Polysaccharida dengan 3 buah hydroksil group pada setiap rantai glucose anhydrous.

Derivat cellulose ini telah banyak digunakan dalam immobilisasi cell dengan menggantikan hydroksil group dengan beberapa gugus pengganti. Penggantian. dengan gugus diethylaminoethyl (DEAE) akan menghasilkan polycationic yang bereaksi basa lemah. Penggantian carbonyl group dengan carbonyl methyl (CM) akan monghasilkan carbonyl group yang bereaksi asam iemah.

Derivat-derivat cellulose lain yang bisa digunakan adalah dari mono, di, tri acetate cellulose yang bersifat base fibrous.

\section{PENGGUNAAN IMMOBMLISASI CELL}

Telah banyak penelitian penggunaan immobilisasi cell mtikrobia untuk penanganan limbah cair industri, Yang P.Y. dan Wong M.L. telah mencoba menggunakan mono carrier (cellulose tri acetate) dan bi carrier (kombinasi Calsium Alginat dan Cellalose tri acetate) untuk mengimmobilisasi cell biomas dari hasil aklinatasi dengan menggunakan limbah sintetis yang mengandung glucose dan phenol.

Adapun komposisi limbah sintetis yang digunakan adalah sebagai berikut :

$\begin{array}{ll}\text { Phenol } & 250 \mathrm{mg} / \mathrm{l} \\ \text { Ammonium Sulphate, (NH4)2SO4 } & 250 \mathrm{mg} / \mathrm{l} \\ \text { Calsium Cnlorida, CaCl2 } & 3.75 \mathrm{mg} / \mathrm{l} \\ \text { Ferry Chlorida, FeCl3.6H2O } & 0.25 \mathrm{mg} / 1 \\ \text { Magnesium Sulfat, MgSO4.H2O } & 50 \mathrm{mg} / 1 \\ \text { Magnesium Sulfat, MgSO4.7H2O } & 50 \mathrm{mg} / 1 \\ \text { Mono Potasium Phospate, KH2PO4 } & 5 \mathrm{mg} / \mathrm{l} \\ \text { Di Potasium Phospate, K2HPO4 } & 535 \mathrm{mg} / 1 \\ \text { Air } & 50 \mathrm{mg} / 1\end{array}$

Untuk penyiapan immobilisasi cell dapat dilakukan sebagai berikut :

a. Mono-Carrier

$1.000 \mathrm{ml}$ larutan $10 \%$ cellulose tri acetate, dicampur homogen dengan $20 \mathrm{mg}$ suspensi $25 \%$ cell mikrobia, gel yang diperoleh diekstrusikan menggunakan alat suntikan kapasitas $20 \mathrm{ml}$ tanpa menggunakan jarum, masa yang terbentuk likeraskan dengan cara mencelupkan dalam 100 ml larutan toluena, kemudian 
dikeringkan dan diangin-anginkan.

b. Bi-Carrier

Imobilisasi cell dengan bi carrier dilakukan dengan mencampur campuran 25 $\mathrm{ml}$ larutan $3 \%$ Natrium alginate dan $2,5 \mathrm{~g}$ suspensi $40 \%$ cell dengan $75 \mathrm{ml}$ larutan $10 \%$ cellulose triacetate dengan $3,75 \mathrm{~g}$ suspensi $25 \%$ cell.

Campuran yang didapat akan berupa gel yang kemudian diekstrusikan dan dibentuk sebagai jaringan, kemudian dikeringkan dengan cara diangin-anginkan dan bentuk alginate gel dikeraskan dengan $0,1 \mathrm{M}$ larutan $\mathrm{CaCl} 2$, cuci dengan air.

Dalam penggunaannya mono dan bi carrier immobilisasi cell ditempatkan terpisah berturut-turut masing-masing pada tube volume $250 \mathrm{ml}$ dan $500 \mathrm{ml}$ yang dilengkapi dengan diffuser dan pompa untuk influent, aliran udara dalam tube dengan kecepatan $1 \mathrm{l} / \mathrm{min}$ dan temperatur operasi $25 \pm 1^{\circ} \mathrm{C}$. Dalam operasinya digunakan loading rate yang dinaikkan secara bertahap mulai dari 3 hingga 9 gram COD/1/ hari. Untuk bi carrier dari 1,5 hingga 18 gram $\mathrm{COD} / 1 /$ hari untuk mono carrier, sedangkan waktu tinggal turun dari 5 hingga 1,5 jam untuk bi carrier dan dari 10 hingga 0,7 untuk mono carrier.

Dari hasil penelitian Yang P.Y. menyimpulkan bahwa cell immobilitas baik mono maupun bi carrier bisa digunakan untuk mengolah limbah yang mengandung derivat phenol. Dengan loading rate 9,5 gram $C O D / 1 /$ hari dapat dicapai efficency penurunan COD sampai dengan $90 \%$ atau lebih dan stabilitas operasional dicapai pada loading rate 3 gram COD/1/hari.

Percobaan juga telah dilakukan dengan immobilisasi lumpur aktiv dengan metode polyvinyl alkohol (PVA)-asam borat, yaitu dengan menggunakan PVA sebagai carrier yang dilarutkan dalam air sampai kadar 15 - $20 \%$ dan dengan lumpur aktiv 120 gram/1. Percobaan secara kontinyu dengan loading total organik karbon antara 0,5 - 2,35 gram TOC/1/hari diketahui dapat menurunkan kadar Total Organik Carbon sampai dengan $93 \%$ dan Total Nitrogen $30-40 \%$.

\section{KESIMPULAN}

Dari uraian diatas dapat disimpulkan bahwa penggunaan metode cell mikrobia yang di immobilisasi dapat digunakan untuk penanganan limbah cair industri dengan effektivitas yang cukup tinggi untuk limbah yang mengandung bahan toksik seperti phenol.

Metode ini juga memberikan keuntungan dibanding dengan metode konvensional, karena dengan metode ini tidak diperlukan lagi bak pengendap sekunder dari recycle sludge.

\section{DAFTAR PUSTAKA}

1. Yang P.Y. (1987), Immobilized Mixed Microbial Cells for Waste Water Treatment, Agriculture Engineering Department University of Hawaii, Hawaii 96822.

2. Lorenz O., at all (1987), Immobilization of Yeast Cells in Polyurethane Ionomers, Bio Technology and Bio Engineering Vol. XXIX, p. 388, John Wiley \& Sons Inc. 